\title{
https://doi.org/10.46344/JBINO.2020.v09i05.16
}

\section{FABRICATION OF SMALL SCALE BIOGAS GENERATOR UTILIZING DOMESTIC WASTES FOR HOME APPLICATIONS}

\author{
RAMESH P L N ${ }^{1}$ and K. CHOLAPANDIAN ${ }^{2}$
}

1. Department of Mechanical Engineering, PRATHYUSHA ENGINEERING COLLEGE: THIRUVALLUR CHENNAI -602025

2. Department of Biotechnology, PRATHYUSHA ENGINEERING COLLEGE: THIRUVALLUR CHENNAI -602025

Email : hod.biotech@prathyusha.edu.in

\begin{abstract}
In the search for alternate energy source much attention is focused on biogas generation. Biogas is an efficient energy source from waste material. There is an exponential increase in generation of solid waste which directly affects the Indian economy. In order to minimize the solid wastes especially kitchen waste various methods are being used but using it for the production of biogas is one of the best approach. The method is cost effective, ecofriendly and also produces high quality renewable fuel. It is also used to reduce $\mathrm{CO} 2$ and $\mathrm{CH} 4$ emission into the atmosphere. The aim of the project is to design a home -use biogas generator using locally available organic wastes. Optimizing the production of biogas by using various quantity of kitchen waste and banana peel will be home friendly to use. So attempt has been made to design a novel anaerobic digester in which kitchen waste and banana peel were used as raw material. The $\mathrm{pH}$ values of the slurry, total solid and volatile solid and best retention period for optimum biogas production were analyzed periodically. At the retention period of 16-18 days the banana peel biogas generator produced $2350 \mathrm{ml}$ biogas /day. The Biogas produced was purified and stored using gas holding setup. It was found that the rate of Biogas production was much faster by using banana peels on comparing with kitchen waste
\end{abstract}

Keywords: Solid waste, Kitchen waste, Banana waste, Biogas generator 
The other major issue in recent years is the depletion of the fossil fuels which are the primary source of energy. Thus a new source of energy is required which is should be simple and efficient. Renewable energy sources can be used for solving energy crisis. In this domain biogas is one of the low cost renewable energy sources which can be produced easily and also eco-friendly. Biogas is the only answer for the above mentioned issues in which it reduces the emission of methane into the atmosphere which causes global warming and also it can be used as an alternate energy source to overcome the depletion of non renewable fossil fuel resources[Tock et al., 2010].Further today the disposal of organic wastes from domestic activities and agriculture related activities has become a major issue. There is an exponential increase in generation of solid organic wastes which directly affects the Indian economy. The kitchen wastes and banana peel wastes from home, hostels, consumer units and hospitality sectors are enormous and are thrown away in open places. Such wastes have high energy value but are not used efficiently. These wastes are normally dumped in landfills and unregulated dumping grounds forming huge masses of putrefying wastes that attract rodents, insects, scavengers, spread diseases, contaminate water sources and generate fouls odours[Ziana et al.,2015 ]. In order to minimize the solid wastes especially kitchen wastes and banana peel waste various methods are being used to get manure but using it for the production of biogas is one of the best approaches. Kitchen waste has high biodegradability, calorific value and good medium for microbial growth and can be well used to generate biogas [ labal et al.,2014 ]. Deshpande et al., [2019] designed a biogas digester for kitchen wastes. The bio-gas technology is considered as one of the best technologies for treating organic wastes [Pandyaswargo et al., 2019]. Fruit wastes are a good organic commodity for sustainable energy production anaerobically [Valenti et al., 2017 ]. Bananas are the major fruit crop with an approximate annual global production of $1.2 \times 108$ t. and several tons of peels, fibers, and leaves are generated during the production and processing of bananas .So a sustainable banana peels generation can be obtained to continue the biogas production [F A O 2018]. Achinas et al., [2018] examined the effect of organic loading and cow manure addition on anaerobic digester performance using banana peel waste. After a 35 -day of digestion at $37^{\circ} \mathrm{C}$ in $2 \mathrm{~L}$ reactors, banana peel was reported to yield $0.367 \mathrm{~m}^{3} / \mathrm{kg}$ volatile solids (VS) with methane [Tahir et al .2016]. Dhivyabharathi et al., [2018] designed a solid state digester for biogas production using banana peels wastes and the digester was optimized with the daily gas production of $0.7 \mathrm{~m} 3$ with methane content in the range of 56 to $65 \%$.As several tones of banana wastes go wastes every day it can be converted in to a good substrate for biogas production. The efficacy of the banana as a substrate for biogas production is compared with kitchen wastes as 
substrates. Further a low cost biogas reactor was fabricated for domestic application,

\section{MATERIALS AND METHODS}

\section{Biogas digester details}

A novel design for biogas reactor was fabricated[Fig.1] .Digesters were made using 20 liters thick plastic water can.The inlet and outlet pipes were introduced into the reactor and was sealed airtight using M-seal. Valves were fitted at the required places to control the flow of the fluids. Gas valves were used to control the speed. The process is a batch process. Each batch was retained for 3 days in the digester. The temperature of the digester is an important parameter to influence the digestion rate and it was maintained at $37 \pm 2{ }^{\circ} \mathrm{C}$. The digester is modified 20 liter thick water can. It was modified with inlets and outlets with valve control [Fig.2] .Substrate digestion takes place inside the digester and biogas is produced due to the action of microbes. Anaerobic microbial digestion is a breakdown of biodegradable material in the substrate in the absence of oxygen. The digestion process begins with the hydrolysis of the input materials to break down insoluble organic polymers, such as carbohydrates, and make them available for other bacteria. Acidogenic bacteria then convert the sugars and amino acids into carbon dioxide, hydrogen, ammonia, and organic acids. Acetogenic bacteria then convert these resulting organic acids into acetic acid, along with additional ammonia, hydrogen, and Carbon dioxide. Finally, methanogens convert these products to methane and carbon dioxide.The time taken by the substrate inside the digester before it comes out after the action of microorganisms in the bioreactor is called retention time. Retention time is one the key factors that controls the extent to which volatile solids in the substrate are converted to biogas. Hydrolysis of lignocellulose components in $\mathrm{KW}$ and $\mathrm{BP}$ resulting in reducing sugars such as glucose, hexoses and pentose which are metabolized by the anaerobic microbes in the digester .An estimation of reducing sugar will help to understand microbial action in the biogas production.

\section{Source of kitchen wastes}

Kitchen waste used for study was collected from Prathyusha Engineering College mess. It contained a mixture of vegetables wastes like beans, carrots, and potatoes. Using mixer grinder the wastes along with water was crushed and made into slurry.

\section{Source of banana wastes:}

For the study banana peels were collected from Prathyusha Engineering College mess. The peels were chopped into several pieces and were dried at to remove the moisture content. Then the dried pieces were taken and powdered using pulveriser.[Fig.3]

\section{Cow dung collection:}

Cow dung was collected from the college farm house. It was used as a seedling for both the kitchen and banana peels. Cow dung was used to induce microbial action.

\section{Utilization of kitchen waste (KW) as substrate in R1 Reactor}

To enhance the generation of biogas in the anaerobic digester pre- 
digestive processing was done using cow dung slurry. The pre digester was filled with the substrate where the hydrolysis takes place. Pre digestion helps to reduce the retention time in the digester. The cow dung slurry was prepared by mixing water in the ratio 1:1.The kitchen wastes were ground to a paste form in a pulveriser and loaded in the digester. The substrate was mixed with water in the ratio of 1:2 to make slurry. The cow dung slurry was prepared by mixing water in the ratio 1:1 and $1000 \mathrm{ml}$ was added to digester. After that, every day $\mathrm{pH}, \mathrm{TS} \%$, vS\% values were noted. When the predigested $\mathrm{KW}$ begins to release gas $\mathrm{pH}$ value starts decreasing indicating acidosis. When there was a constant decrease in the $\mathrm{pH}$ value the control valve was opened thus the hydrolyzed substrate enters the digester [R1]. Various concentrations of kitchen wastes were allowed into the digester and the amount of biogas produced was checked. In order to find the amount of reducing sugar available for the bacteria to react DNS method was done.

\section{Utilization of Banana peels as a substrate for biogas production-[R 2 Reactor]}

The R2 digester was filled with powered banana peels [BP] .Banana peel powder was mixed with water in the ratio 1:15. The cow dung slurry was prepared by mixing water in the ratio 1:1 and $1000 \mathrm{ml}$ was added to digester. After that, every day $\mathrm{pH}, \mathrm{TS} \%$, vS\% values were noted. Hydrolysis takes place at a faster rate in the pre-digester because of the presence of certain sugars When the predigested BP begins to release gas $\mathrm{pH}$ value starts decreasing indicating acidosis. When there was a constant decrease in the $\mathrm{pH}$ value the control valve was opened thus the hydrolyzed substrate enters the digester [R2]. The pre digestion reduces the retention time. When the $\mathrm{pH}$ stabilized various concentrations of banana peel was allowed into the digester. Thus it was available ready made for the methanogens to consume and produce methane. In order to find the amount of reducing sugar available for the bacteria to react DNS method was done

\section{ANALYSIS OF BIOGAS PRODUCED}

The amount of biogas produced was quantified daily using Height difference method. In this method the minimum and maximum points were marked in the gas holder. The gas valve was opened and closed in order to mark the initial and the final height. The difference in the height gives the volume of biogas produced.

Burn method: Burn method was used to assess qualitative properties of the released biogas. In this method, Bunsen burner was used to burn the produced biogas. Daily burning after the addition of substrates was also recorded to know the rate of biogas production[Fig.4].

\section{ANALYTICAL METHODS \& CALCULATIONS}

TOTAL SOLIDS (TS \%) - To estimate total solid content the amount of solid present in the sample after the water contents gets evaporated was measured. Approximately $10 \mathrm{~g}$ of the sample, was taken and poured in foil plate and dried at $105^{\circ} \mathrm{C}$ in a furnace and the weight of the left substrate was recorded 
TS \% = (Final weight/Initial weight) $\times 100$ VOLATILE SOLIDS (VS \%) - Dried residue after Total Solid analysis was weighed and heated in crucible for $2 \mathrm{hrs}$ at $500^{\circ} \mathrm{C}$ in furnace. After cooling the residue in the crucible was weighed.

VS $\%=[100-(V 3-V 1 / V 2-V 1)] \times 100$

$V 1=$ Weight of crucible

V2= Weight of dry residue \& crucible

V3 = Weight of ash \& crucible (after cooling)

\section{GLUCOSE ASSAY BY DINITROSALICYLIC C OLORIMETRIC}

\section{METHOD [DNS Method]}

Seven clean, dry test tubes were taken and standard sugar solution in the range of 0 to $3 \mathrm{~mL}$ were Pipetted out in different test tubes and made up the volume of all test tubes to $3 \mathrm{~mL}$ with distilled water One $\mathrm{mL}$ of dinitrosalicylic acid [DNS] reagent was added to all the test tubes and mix plug the test tube with cotton or marble and kept the test tube in a boiling water bath for 5 minute and after cooling optical density value of each test tubes were measured at $540 \mathrm{~mm}$ against the blank using spectrophotometer. Reducing sugar present in KW and BP slurry in the biogas digester was measured by comparing its $O D$ value with that of standard solution.[Fig.5 ].

\section{RESULTS AND DISCUSSION}

The Values of $\mathrm{pH}, \mathrm{TS} \%, \mathrm{VS} \%$ and volume of biogas produced was recorded for30 days. It was found that as the retention time increased, the values of $\mathrm{pH}, \mathrm{TS} \%$, and VS\% decreased. This is due to the production of acids during the acidogenesis stage. Further the acidogenesis reduce the methanogenic bacterial activity .The biogas production decreased when $\mathrm{pH}$ moves towards acidic state. A good biogas production is a reflection of methanogenic bacterial action and it was seen in both reactors $\mathrm{R} 1$ andR2 during $16-21$ days of retention time. Although the biogas production increased with the substrate retention time, beyond 21 days the production of biogas was reduced due to the development of acidic $\mathrm{pH}$ and the subsequent inability of methanogenic bacteria to remain in active state. From the observation it is evident that the activity of methanogenic bacteria is optimum when $\mathrm{pH}$ is near to normal $[\mathrm{pH}$ 6.8-7.3] in both the reactors[Table 1-3]. The volume of biogas produced increased at a constant rate. From the results it is seen that $\mathrm{pH}$ influences the anaerobic digestion and biogas release. In the reactor [R1] which contains banana peel wastes, the $\mathrm{pH}$ decreased fast because the reaction was fast. It is noted that the hydrolysis and acidogenesis reaction in banana peel reactor are fast because the anaerobic microbes utilized the banana peel waste more speedily than kitchen wastes in the reactor R2. The degradation of raw material in the digester decides the biogas production. The degradation is faster if the loaded raw material has low fiber content. [Cirne et al., 2007]. The faster degradation rates of the substrates depend on non-structural carbohydrates content.[ Chakrabarti et al., 1999 ] In the banana peel, as fibre content is less it gets degraded fastly [Gumisiriza et al ., 2018 ]. Hence it can be well used in biogas production. If the $\mathrm{pH}$ value drops to acidic levels, the medium will be toxic to the 
methanogenic bacteria . Chandra et al., [2012] stated that methanogenic bacteria are sensitive to both high and low $\mathrm{pH}$ and grow better in $\mathrm{pH}$ range of 6.5 and 8 . As the methanogenic bacteria are sensitive to acidic environment the optimum $\mathrm{pH}$ for biogas production is recommended in the range of 6.8-7.2 [Cammarota et al ., 2001 ] . The $\mathrm{pH}$ influences the activity of microorganisms and enzymatic activity as they are both active within certain narrow $\mathrm{pH}$ ranges [Ge et al ., 2020 ] . However, due to the formation of different intermediates, $\mathrm{pH}$ varies within each phase of anaerobic digestion. At the same time, the different microbial groups involved in each phase require different $\mathrm{pH}$ conditions for optimum growth. This stratification of $\mathrm{pH}$ along phases of anaerobic digestion affects the growth of certain microorganisms differently. In general, hydrolytic and acidogenic bacteria prefer slightly acidic conditions near $\mathrm{pH}$ 6[Alayil et al .2016 ]. Optimal pH for acidogens has been reported in the ranges of $\mathrm{pH}$ 5.5-6.5 [Khalid et al ., 2011] and 5.8-6.2 [Tominac et al.,2020 ] .In contrast, acidic conditions are toxic to methanogenic bacteria, which prefer neutral conditions in the range of $\mathrm{pH}$ 6.58.2 [Ge et al ., 2020 ].The growth rate of methanogens falls sharply below pH 6.5 [Amir et al ., 2019 ] The pH-related inhibition of microorganisms in anaerobic digestion process is caused by reactor imbalances between compounds such as ammonia and volatile fatty acids. As a result, acid accumulation is one of the biggest potentials for anaerobic digester failure. Thus to ensure stable operation in batch bioreactors (one-stage anaerobic digestion process), $\mathrm{pH}$ should be maintained between 6.7 and 7.4
[Achinas et al ., 2019]

In a properly balanced reactor, $\mathrm{pH}$ can be buffered through the generation of bicarbonate by methanogens. Providing excess alkalinity through blending of high carbohydrate waste feedstock with alkaline compounds or appropriate substrate co-digestion can buffer the AD process against inhibition due to excess acid accumulation

In the present study the amount of total solid, volatile solid and biogas production per day in the reactors were traced from day 1 to 30 days of retention of substrates in the reactors [ Table 7]. In the initial retention time 1-3 days the TS, VS, biogas production in the banana peel reactor were $7.4 \%, 86.8 \%$ and $400 \mathrm{ml} /$ day biogas output. In the kitchen waste reactor TS, VS and biogas production during 1-3 days of raw material retention were $8.83 \%$, $92.7 \%$ and zero $\mathrm{ml}$ of biogas output. During 16-18 days of substrate retention time in banana peel bioreactor the TS, VS and biogas production were $4.8 \%$, $71.4 \%$ and $2350 \mathrm{ml} /$ day respectively. But in kitchen waste reactor TS, VS and biogas output were $6.7 \%, 84.1 \%$ and 1900 $\mathrm{ml} /$ day. During 16-18 days of retention the TS in banana peel reactor was $1.9 \%$ lower than kitchen waste reactor. The VS percentage in banana peel reactor was $71.4 \%$ but it was $84.1 \%$ in kitchen waste reactor. The lower the VS and TS the greater the biogas output up to an optimum level. In the BP reactor biogas production was $450 \mathrm{ml} /$ day higher than $\mathrm{KW}$ reactor during 28-30 days of retention time. The study shows that BP is a good raw material than kitchen wastes for bio gas production. Divyabharathi et al., [2018] also reported that the lower ino.com | Innovative Association 
percentage of volatile solid in banana peel promote its efficiency in biogas yield. Pretreated banana peels with cow manure co-digestion enhances biogas

\section{FIGURES AND TABLES}

\section{FEED INLET}

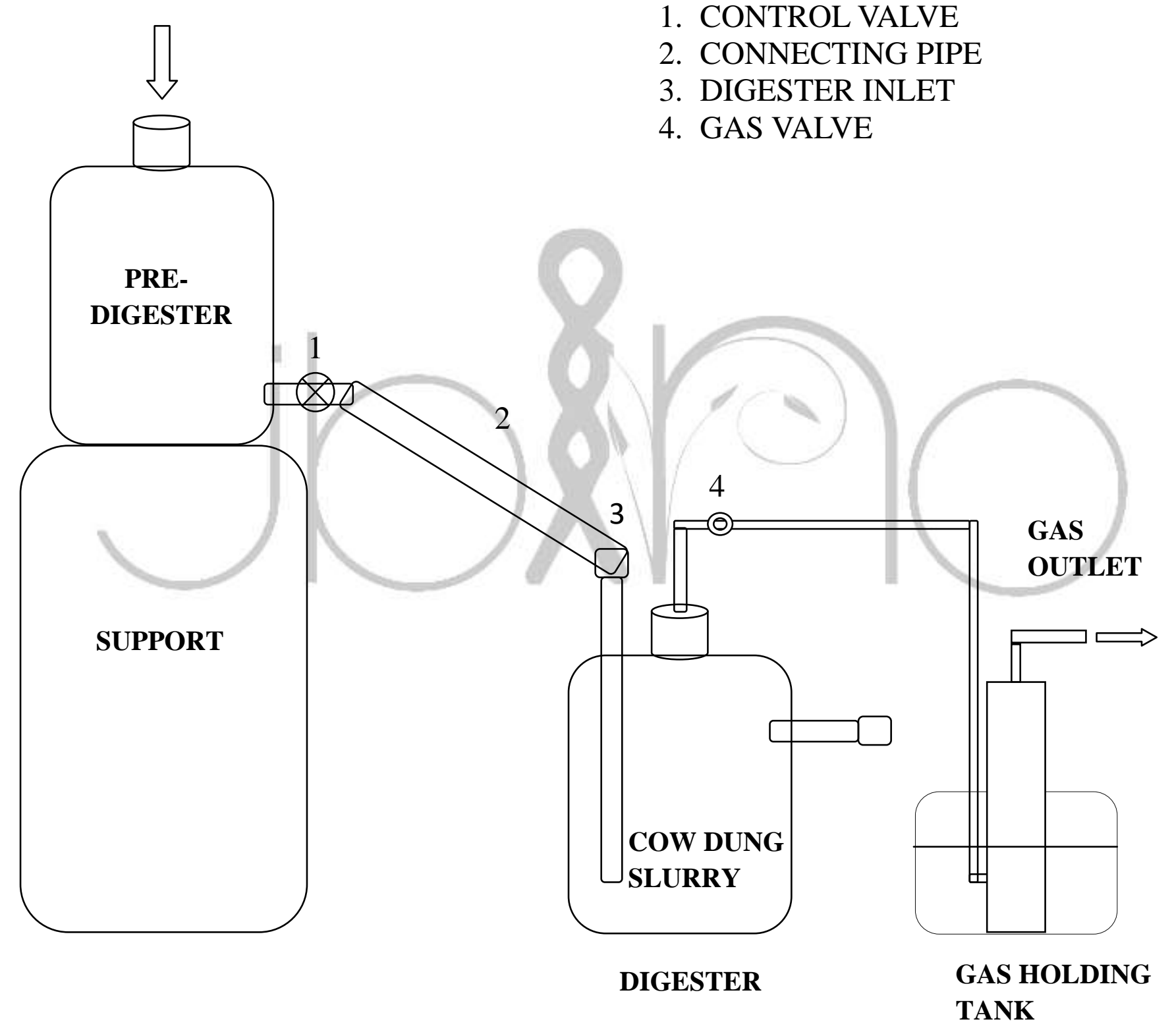

Fig .1 .Digester design 


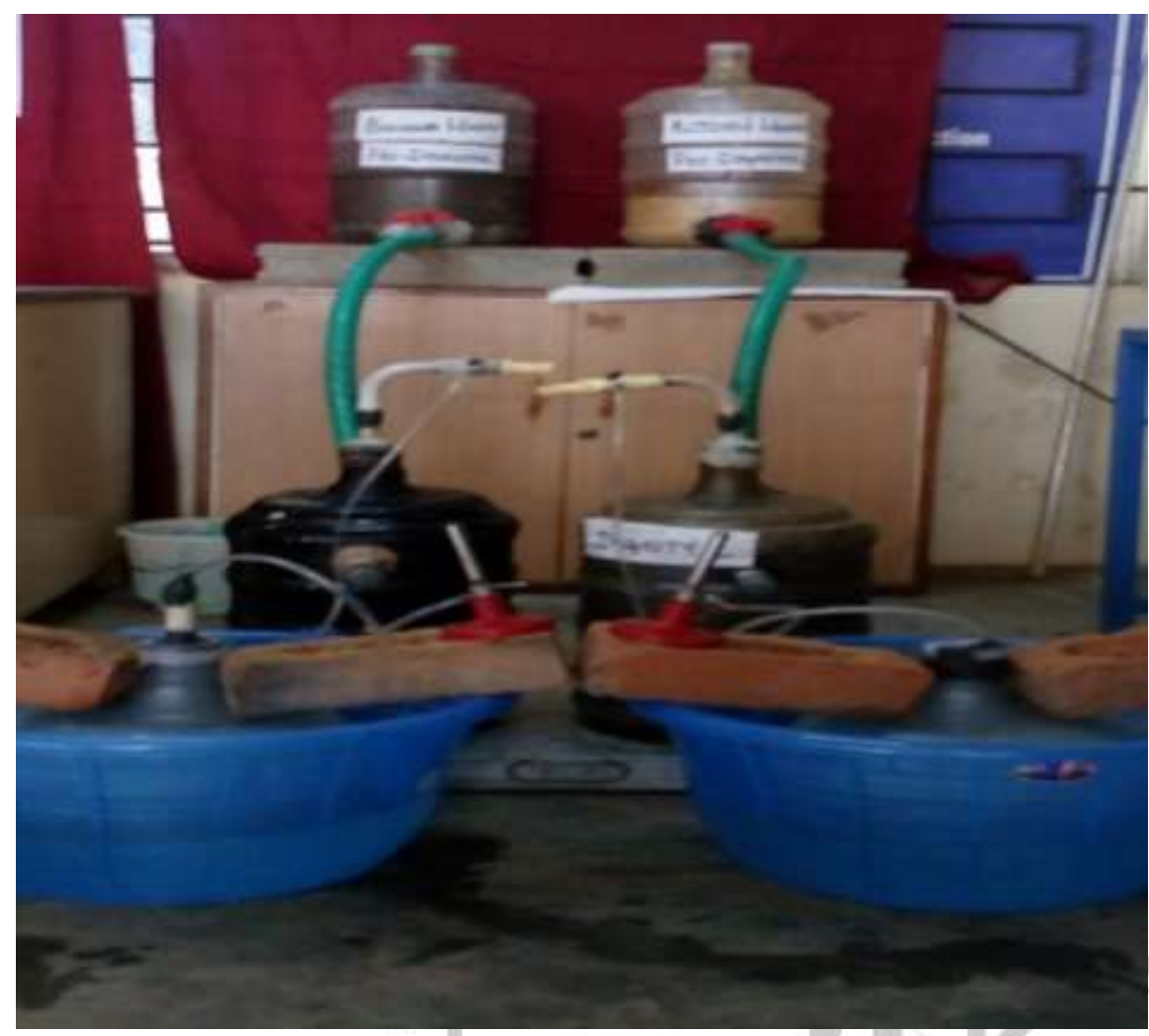

Fig.2. BIOGAS PRODUCTION UNIT

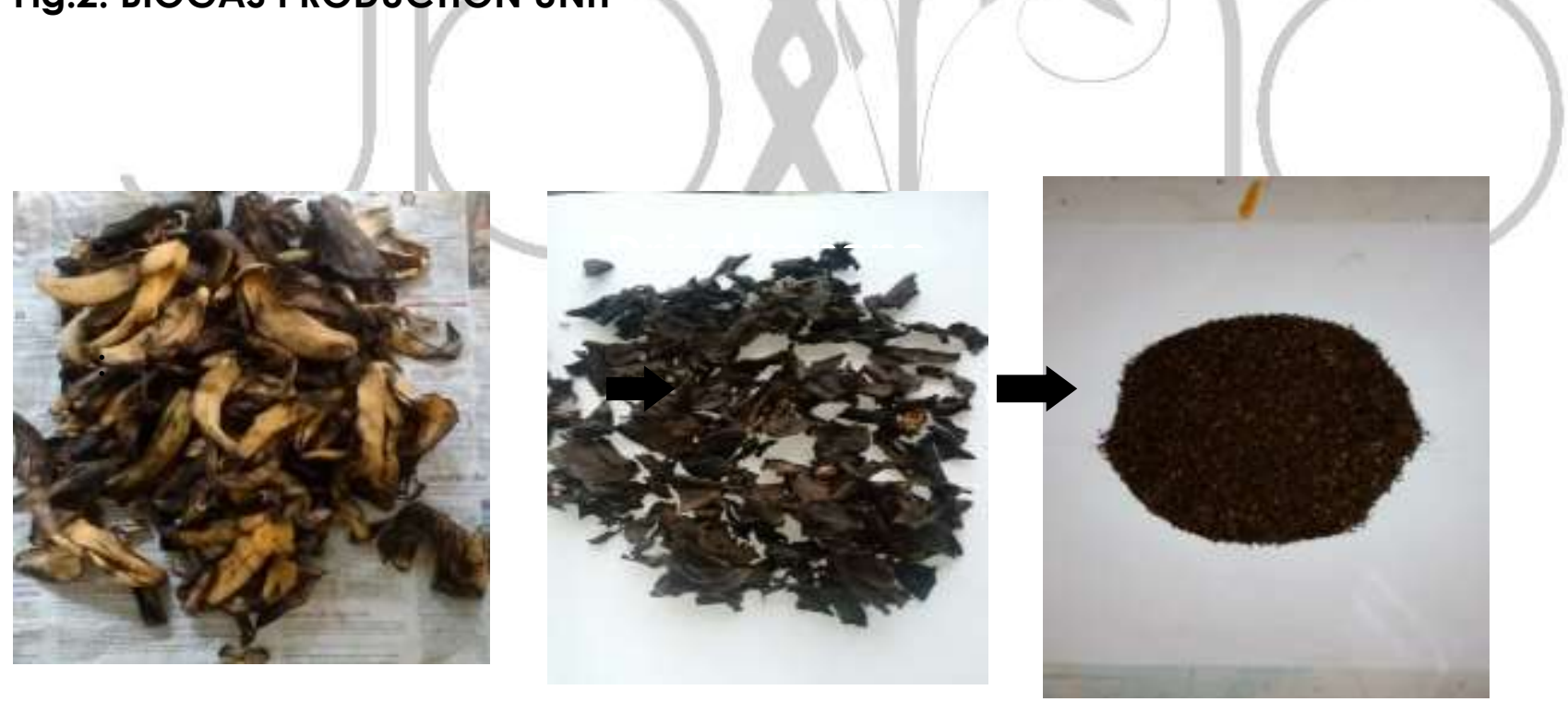

Fig. 3.Banana peel preparation 

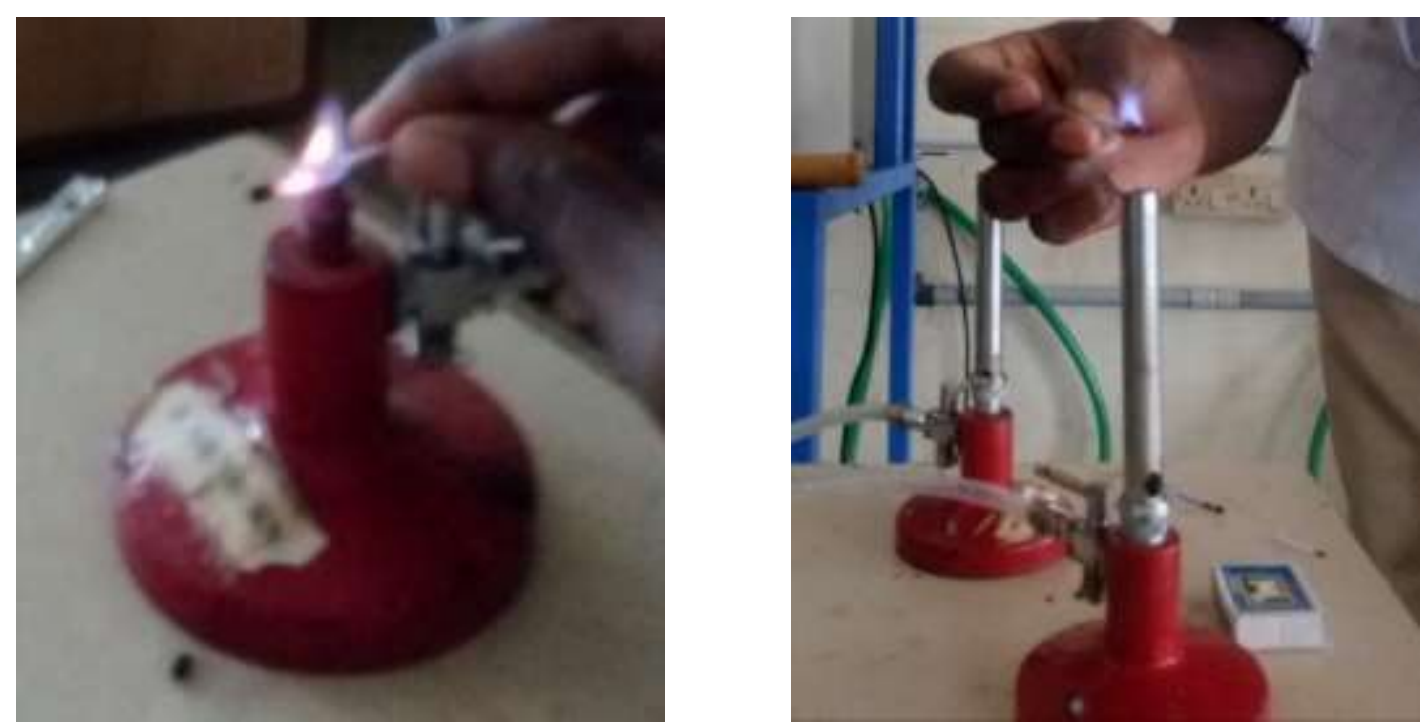

Fig. 4: Testing biogas production

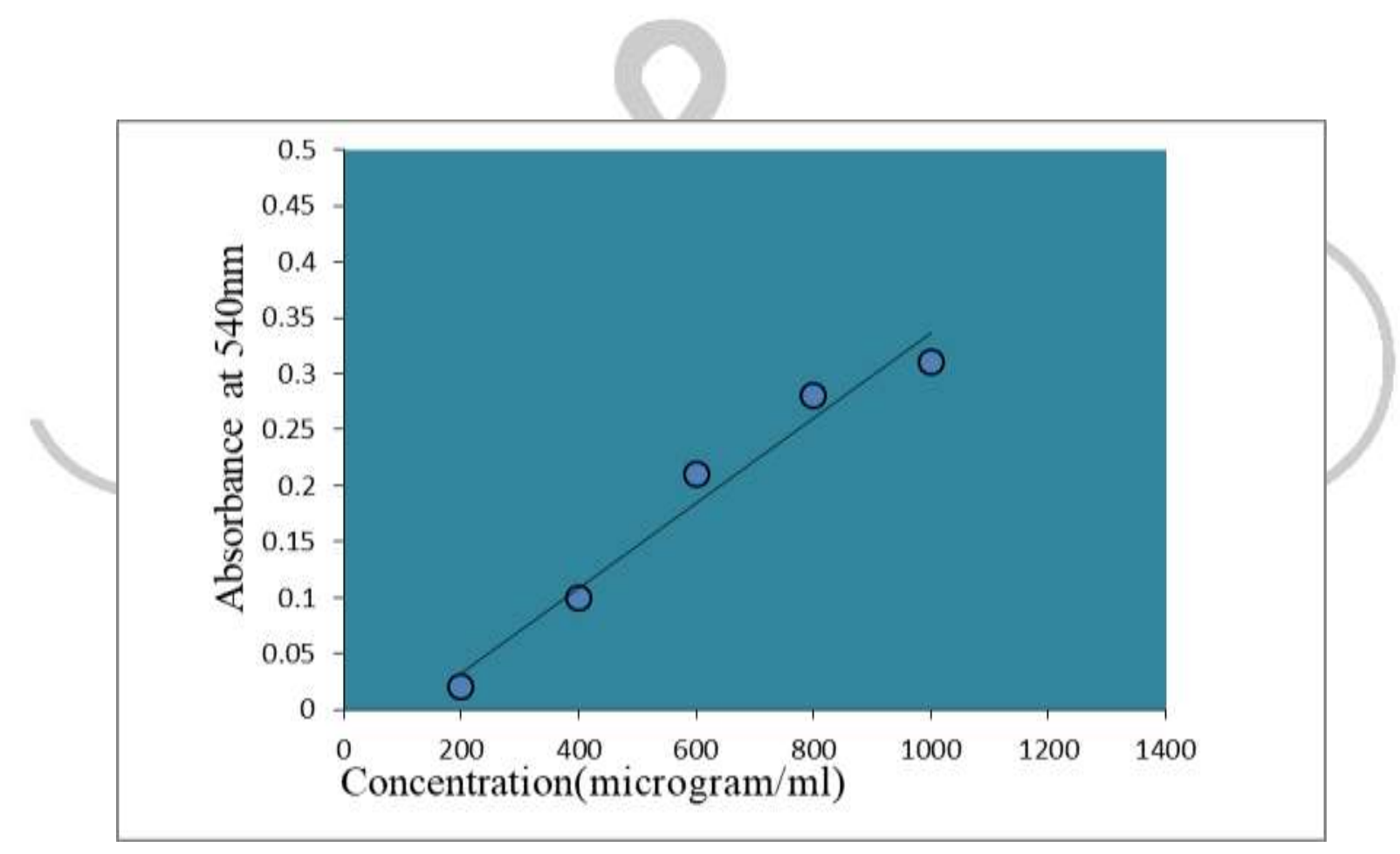

Fig. 5. Standard Graph for Reducing Sugar 
TABLE 3.COMPARATIVE PERFORMANCE ANALYSIS OF BIOGAS REACTOR USING KITCHEN WASTES AND BANANA PEEL WASTE

\begin{tabular}{|l|l|l|l|l|l|l|}
\hline $\begin{array}{l}\text { Retention } \\
\text { time(days) }\end{array}$ & $\begin{array}{l}\text { TS\% of } \\
\text { BP }\end{array}$ & $\begin{array}{l}\text { TS\% of } \\
\text { KW }\end{array}$ & $\begin{array}{l}\text { VS\% of } \\
\text { BP }\end{array}$ & $\begin{array}{l}\text { VS\% } \\
\text { KW }\end{array}$ & $\begin{array}{l}\text { Gas } \\
\text { Produced } \\
\text { using } \\
\text { (ml/day) }\end{array}$ \\
BP \\
$1-3$
\end{tabular}


Table 1: DNS Standard value

\begin{tabular}{|l|l|}
\hline $\begin{array}{l}\text { Concentration of working } \\
\text { standard (microgram/ml) }\end{array}$ & $\begin{array}{l}\text { Absorbance value OD at } \\
\mathbf{5 4 0} \mathbf{n m}\end{array}$ \\
\hline Blank & 0 \\
\hline 200 & 0.02 \\
\hline 400 & 0.10 \\
\hline 600 & 0.21 \\
\hline 800 & 0.28 \\
\hline 1000 & 0.31 \\
\hline Dry Banana Peel (BP) & 0.68 \\
\hline Kitchen Waste (KW) & 0.46 \\
\hline
\end{tabular}

Table 2.pH of different substrate -Kitchen waste $[\mathrm{KW}]$ and Banana peel [BP] co-digested with cow dung

\begin{tabular}{|c|c|c|}
\hline Retention time (days) & $\begin{array}{c}\text { pH of KW co- } \\
\text { digested with CD }\end{array}$ & $\begin{array}{c}\text { pH of BP } \\
\text { co-digested with CD }\end{array}$ \\
\hline $1-3$ & 8.6 & 8.2 \\
\hline $4-6$ & 8.5 & 8.1 \\
\hline $7-9$ & 8.1 & 7.9 \\
\hline $10-12$ & 7.8 & 7.5 \\
\hline $13-15$ & 7.6 & 7.3 \\
\hline $16-18$ & 7.3 & 7.2 \\
\hline $19-21$ & 7.1 & 7.1 \\
\hline $22-24$ & 6.8 & 6.9 \\
\hline $25-27$ & 5.6 & 5.4 \\
\hline $28-30$ & 5.2 & 4.8 \\
\hline & & \\
\hline
\end{tabular}


In the present study the amount of total solid, volatile solid and biogas production per day in the self- designed reactors in which predigested kitchen wastes and banana peel co mixed with cattle dung were used as substrates.

During 16-18 days of substrate retention time the banana peel bioreactor produced $2350 \mathrm{ml}$ of biogas /day But in kitchen waste reactor it was 1900 $\mathrm{ml} /$ day. The biogas production was found influenced by $\mathrm{pH}$ and nature of the substrate used. The presently designed biogas reactor using domestic waste can be patented to produce in a mass scale to beneficially use for home applications.

\section{ACKNOWLEDGEMENT}

Both the authors have contributed equally in this work

\section{REFERENCES}

Achinas S ., Janneke K., Gerrit J.and Willem E., Enhanced Biogas Production from the Anaerobic Batch Treatment of Banana Peels, Engineering ,5 970978(2019). .

\section{Achinas S., Achinas V.and Euverink} G.J.W., A technological overview of biogas production from bio waste, Engineering , 3 (3), 299-307[2017]

Amir Izzuddin Adnan, Mei Yin Ong, Saifuddin Nomanbhay , Kit Wayne Chew and Pau Loke 2019 Show Technologies for Biogas Upgrading to Biomethane: A Review Bioengineering 2019, 6, 92; doi:10.3390/bioengineering6040092

Cammarota M.C., Teixeira G.A. and Freire D.M.G., Enzymatic pre-hydrolysis and anaerobic degradation of wastewaters with high fat contents. Biotechnology Letters., 23,1591-15 95[2001]

\section{$\begin{array}{llll}\text { Chakrabarti S .K., } & \text { Biphasic }\end{array}$} biomethanation of wood-hydrolysate effluent. Artif Cells Blood Substit Immobil Biotechnol, 27(5-6):46[1999]

Chandra R., Takeuchi H. and Hasegawa T., Methane production from lignocellulosic agricultural crop wastes: a review in context to second generation of biofuel production. Renew Sustain Energy Rev., 16(3),1462-76[2012]

Cirne D.G., Lehtomaki A., Bjornsson L. and Blackall L.L., Hydrolysis and microbial community analyses in two-stage anaerobic digestion of energy crops. J Appl Microbiol, 103, 516-27 [2007]

Deshpande S ., Heena J ., Varsha B ., Soniya K., Ankita K, and Sandesh D., Design of Floating Biogas Digester and Productio of Biogas using Kitchen Waste., IJERT., 08 , 06 [2019]

Divyabharathi R., Angeeswarans. PugalendhilK, and JagadeeshK., Performance Evaluation of Solid State Digester for Biogas Production from Banana Wastes, Chem Sci Rev Lett, 7(25), 12-18[2018]

Food and Agriculture Organization of the United Nations; Commodity markets monitoring and outlook: bananas cited March'http://www.fao.org/economic/est /estcommodities/bananas/en [2018]

Ge S., Ma, J., Liu, L. and Yuan Z., The Impact of Exogenous Aerobic Bacteria 
on Sustainable Methane Production Associated with Municipal Solid Waste Biodegradation: Revealed by HighThroughput Sequencing. Sustainability.,

\section{$12,1815[2020]$}

Gumisiriza, R., Hawumba, J.F., Okure, M. et al. Biomass waste-to-energy valorisation technologies: a review case for banana processing in Uganda. Biotechnol Biofuels 10, 11 (2017). https://doi.org/10.1186/s13068-016-0689

13 labal .S A., Shahinur R., Mizanur R, and Abu $Y$.,Anaerobic Digestion of Kitchen Waste to Produce Biogas., Procedia Engineering., 90, 657-662[2014]

Khalid A., Arshad M., Anjum M., Mahmood T. and Dawson L., The anaerobic digestion of solid organic waste., Waste Manag., 31(8),17371744[2011]

\section{Pandyaswargo A.H., Jagath Dickella Gamaralalage, P., Liu C., Knaus} M.,Onoda H., Mahichi F. and Guo Y., Challenges and An Implementation Framework for Sustainable Municipal Organic Waste Management Using Biogas Technology in Emerging Asian Countries. Sustainability.,11, 6331[2019]

Petravić-Tominac, V., Nastav, N., Buljubašić, M. et al. Current state of biogas production in Croatia. Energ Sustain Soc 10, $8 \quad$ (2020). https://doi.org/10.1 186/s 13705-020-0243-y 17.Reza Alayi1, Ali Shame, Alibakhsh Kasaeian , Hossein Harasii and Majid Amani Topchlar The role of biogas to sustainable development Journal of Chemical and Pharmaceutical Research, , 8(4):112-118[2016
Tahir M. , Khan M., Brulé C.,Maurer D .Argyropoulos J. and Müller., Agric Eng Int: CIGR Journal, 18, (91),110-124[2016]

TockJ.Y., Chin L . L., Keat T. L., Kok T. T. and Subhash k., Banana biomass as potential renewable energy resource A Malaysian case study Renewable and Sustainable Energy Reviews.,14(2), 798-805 [ 2010],

Valenti F ., Porto S. M. C., Cascone G. and Arcidiacono $C$.Potential biogas production from agricultural by-products in Sicily. A case study of citrus pulp and olive pomace. J Agric Eng .,48 (4), 196202. [2017]

Ziana Z., and Rajesh P., Production and Analysis of Biogas from Kitchen Waste., 02 (04) [2015] 